Annals of Warsaw University of Life Sciences - SGGW

Land Reclamation No 44 (1), 2012: 55-62

(Ann. Warsaw Univ. of Life Sci. - SGGW, Land Reclam. 44 (1), 2012)

\title{
Occurrence of nitrogen cycle bacteria in the Biebrza River
}

\author{
MAGDALENA FRAূK ${ }^{1}$, IGNACY KARDEL ${ }^{2}$, URSZULA JANKIEWICZ ${ }^{3}$ \\ ${ }^{1}$ Department of Environmental Improvement, Warsaw University of Life Sciences - SGGW \\ ${ }^{2}$ Department of Hydraulic Engineering, Warsaw University of Life Sciences - SGGW \\ ${ }^{3}$ Department of Biochemistry, Warsaw University of Life Sciences - SGGW
}

\begin{abstract}
Occurrence of nitrogen cycle bacteria in the Biebrza River. This paper of the selected groups of nitrogen cycle bacteria in the Biebrza River was analysed. In the water samples the quantity of ammonifying bacteria, nitrifying bacteria, proteolitic bacteria was estimated and also selected water quality indicators were analysed. Large quantities of proteolitic bacteria and ammonifying bacteria were found while the quantity of nitrifying bacteria was very small. Water quality analyses proved high TOC concentrations and low nitrate as well as nitrite concentrations. It was found, that the mineral forms of nitrogen being the intensive product of organic matter degradation is not released (low concentrations of ammonia), but it is accumulated in microorganisms cells. Low concentrations of ammonia are limiting for the number of nitrifying bacteria. The seasonal character of the occurrence of all analysed bacteria groups was as well found. The analytical procedure used was adjusted for bacteriological research on rivers of low anthropopressure.
\end{abstract}

Key words: ammonifying bacteria, nitrifying bacteria, proteolitic bacteria, Biebrza River, water quality.

\section{INTRODUCTION}

The bacteria form a particularly vital chain link of matter cycling in water ecosystems. They contribute to the natural self-purification of those ecosystems. The initiation of this process is condi- tioned by the presence of an appropriate physiological group of those bacteria. A quantity of bacteria in an ecosystem is determined by the quality and the quantity of inflowing pollutants, often having allochtonic character. Being exceptionally sensitive to changing environment quality, the bacteria are one of the quickest indicators of appearing disturbance (along with phytoplankton indicators). Then, the analysis of the dynamics of individual microorganisms groups can be the most sensitive method for ecosystem changes record.

Nitrogen is one of key elements in nature. However it has to be transformed into other chemical forms which can be assimilated by different organisms inhabiting the ecosystem, and this transformation is the role played by nitrogen cycle bacteria. Then, this type of bacteria can be one of basic microorganism groups pointing ecosystem pollution changes, especially in the monitoring of the ecosystems of a low inflowing pollutants degree.

The aim of this research is an initial description of the Biebrza River water quality changes through the quantitative analysis of selected nitrogen cycle bacteria. 


\section{MATERIALS AND METHODS}

The research was performed in this paper on the reach of the Biebrza River from Lipsk to Rutkowskie which is $118.5 \mathrm{~km}$ long. Surface water samples were taken at 9 sampling points located along the river course (points no. 1-11, Table 1), in the period from July 2007 to April 2008. Additionally, in the last sampling period, the research area was extended by 5 new sampling points located on selected tributaries to the Biebrza River (points no. 12-16, Table 4).

Surface water samples were taken into pure bottles according to PN-74/ /C0462/01 in three measurement periods: in July and September 2007 and in April 2008. The quantities of the selected bacteria physiological groups were determined, using standard diagnostic base, according to the Polish Norm guidelines. MPN For proteolitic bacteria the general number was estimated (according with PN-74/C-04615/17; in CFU - colony forming units), however for ammonifying bacteria and nitrifying bacteria the MPN (most probable number) was determined. The determination of the ammonifying bacteria and nitrifying bacteria quantities was done at the beginning by the inoculation systems: $3 \times 10 \mathrm{~cm}^{3}, 3 \times 1 \mathrm{~cm}^{3}, 3 \times 0.1 \mathrm{~cm}^{3}$ according to the Polish Norm: PN-74/ C04615/18, PN-77/C04615/20). Next, in consecutive measurement times, the inoculation volumes were gradually changed -for ammonifying bacteria the volumes of water were decreased to $3 \times$ $\times 0.1 \mathrm{~cm}^{3}, 3 \times 0.01 \mathrm{~cm}^{3}, 3 \times 0.001 \mathrm{~cm}^{3}$, however for nitrifying bacteria of the first (I) and the second (II) phase these volumes were increased to $1 \times 50 \mathrm{~cm}^{3}$, $5 \times 10 \mathrm{~cm}^{3}$. Proteolitic bacteria were incubated for 72 hours (in the temperature of $28^{\circ} \mathrm{C}$ ), ammonifying bacteria were incubated for 96 hours $\left(28^{\circ} \mathrm{C}\right)$, while the

TABLE 1. Quantitative characteristic of proteolitic (P) and ammonifying (A) bacteria in measurement points

\begin{tabular}{|c|c|c|c|c|c|c|c|c|}
\hline \multicolumn{3}{|c|}{$\begin{array}{l}\text { Measurement points on the Biebrza } \\
\text { River }\end{array}$} & \multicolumn{6}{|c|}{ Sampling periods } \\
\hline \multirow[b]{2}{*}{$\begin{array}{l}\text { No } \\
\text { point }\end{array}$} & \multirow[b]{2}{*}{ locality } & \multirow{2}{*}{$\begin{array}{c}\text { river } \\
\text { kilometer } \\
\text { from source }\end{array}$} & \multicolumn{2}{|c|}{15.07 .2007} & \multicolumn{2}{|c|}{09.09 .2007} & \multicolumn{2}{|c|}{22.04 .2008} \\
\hline & & & $\begin{array}{c}\mathrm{P} \\
\mathrm{CFU} / \mathrm{ml}\end{array}$ & $\begin{array}{c}\mathrm{A} \\
\mathrm{CFU} / \mathrm{ml}\end{array}$ & $\begin{array}{c}\mathrm{P} \\
\mathrm{CFU} / \mathrm{ml}\end{array}$ & $\begin{array}{c}\mathrm{A} \\
\mathrm{CFU} / \mathrm{ml}\end{array}$ & $\begin{array}{c}\mathrm{P} \\
\mathrm{CFU} / \mathrm{ml}\end{array}$ & $\begin{array}{c}\mathrm{A} \\
\mathrm{CFU} / \mathrm{ml}\end{array}$ \\
\hline 1 & Lipsk & 39.5 & 3724 & 24 & 1961 & 24 & 45 & 230 \\
\hline 3 & Sztabin & 66.8 & nd & nd & nd & nd & 10 & 230 \\
\hline 5 & Dolistowo & 88.8 & nd & nd & nd & nd & 110 & 230 \\
\hline 6 & Goniądz & 106.7 & nd & nd & nd & nd & 30 & 90 \\
\hline 7 & Osowiec & 114.6 & 6453 & $>24$ & 59 & 24 & 130 & 950 \\
\hline 8 & Biały Grąd & 126.5 & 1596 & 24 & 113 & 24 & nd & nd \\
\hline 9 & Brzostowo & 150.6 & 4562 & 24 & 1318 & 24 & nd & nd \\
\hline 10 & Burzyn & 155.5 & 15651 & 24 & 2038 & 24 & 185 & 230 \\
\hline 11 & Rutkowskie & 158.0 & 27067 & 24 & 1465 & 24 & nd & nd \\
\hline
\end{tabular}

nd - no data 
nitrifying bacteria were incubated for 21 days $\left(28^{\circ} \mathrm{C}\right)$.

Moreover, the concentrations of selected water quality parameters were analysed. The concentrations of ammonium, nitrate and nitrite ions were determined adequate to the liquid chromatography method (Dionex ICS-1000). TOC (total organic carbon) and TN (total nitrogen) rates were obtained using the high temperature method (automatic flow analyzer SKALAR Formacs HT/TN), according to ISO 8245 EPA 415.1).

\section{RESULTS AND DISCUSSION}

In July and September 2007 the analyses were performed for 6 sampling points in the Biebrza Upper Basin (point no. 1) and in the Biebrza Lower Basin (points no. 7-11, the river reach of the length $42.5 \mathrm{~km}$ ). The gradual increase in proteolitic bacteria quantities was found along the course of the river, which indicates the increasing organic pollution of water. The determined quantity of the proteolitic bacteria at the analysed river reach ranged from $1596 \mathrm{CFU} / \mathrm{ml}$ to 27067 CFU/ml in July, while in September the recorded value was from 59 to $2038 \mathrm{CFU} / \mathrm{ml}$. It wasn't possible to determine the trends in quantity variation here, however, the results suggest changes in organic pollution degree along the course of the river. Again, in April 2008, (reach of $116 \mathrm{~km}$ length, 6 sampling points) there were found gradual changes in proteolitic bacteria quantities along the course of the river - successively, there was the increase of their quantity at the upper reach, the increase and the decrease of their quantity in the middle reach, and, once more, their increase in the lower reach. The changes in organic pollution (protein pollution) at the examined river reaches can be caused by contaminants input by the Biebrza tributaries, which collect them from neighboring areas (agricultural areas, wetlands) which was proved by the research conducted by Frąk (2010), Kardel et al. (2007), Skoczko (2004). The research performed in this paper discovered also a high quantity of proteolitic bacteria in the inflowing water from the tributaries: from $45 \mathrm{CFU} / \mathrm{ml}$ in the Kosodka River to $2550 \mathrm{CFU} / \mathrm{ml}$ in the Augustowski Cannal, which points at their high organic contamination. The organic contamination of the Biebrza River could be also caused by the inflow of local municipal sewage.

The results of TOC and TN measurements confirm the bacteriological analysis indications. In the analyzed period there were high concentrations of TOC (Table 3) which can classify the Biebrza River waters as highly contaminated (over $0.02 \mathrm{mg} \mathrm{C} / \mathrm{ml}$ ). Rheinheimer (1987) claimed, that geological conditions exert a vital influence on physiochemical properties of surrounding water. The research performed by Kardel et al. (2007), and contemporarily executed analyses on a similar area, confirm a significant influence of wetlands on a high TOC concentration in the Biebrza River water. Water courses draining wetlands wash out organic substances (including humus compounds) from the peat, and then enter them into waters of the Biebrza River. TOC contamination can be also caused by the inflow of local agricultural and urban sewage (Skoczko 2004; Frąk 2010). 
Moreover, the changes in the quantities of proteolitic bacteria, proved in this research, are related with the seasonality of their occurrence. In the cold period there occurs the decline in their quantity (April; Table 1), which is consistent with typical dynamics of bacteria quantity in surface waters (Gotkowska-Płachta 2007; Gołaś i in. 2008a, 2008b).

There were also the analyses of ammonifying and nitrifying bacteria quantities undertaken in the same sampling points as given above. In July the quantity of ammonifying bacteria was determied to be over $24 \mathrm{MPN} / \mathrm{ml}$ of water at every sampling point (Table 1). In order to precisely estimate the quantity of ammonifying bacteria it was resolved to decrease the volume of inoculated water by one order of magnitude. In April 2008 the following inoculation system was applied: $3 \times 0.1 \mathrm{ml}+3 \times 0.01 \mathrm{ml}+3 \times$ $\times 0.001 \mathrm{ml}$. A high quantity of ammonifying bacteria was found (Table 1), that is, from $90 \mathrm{MPN} / \mathrm{ml}$ at the point no. 6 to $950 \mathrm{MPN} / \mathrm{ml}$ at the point no. 7. At the Upper Biebrza reach the number of ammonifying bacteria is similar (points no. $1-5,230 \mathrm{CFU} / \mathrm{ml}$ ), at the Lower Biebrza reach it is subject to strong quantitative variations. In the analysed Biebrza River tributaries (Table 4) there were also found large numbers of occuring ammonifying bacteria (over $2400 \mathrm{MPN} / \mathrm{ml}$ at points: $12,14,15,16)$. The achieved results point at intensive ammonifying processes and, in the same way, they suggest the occurrence of high ammonium concentrations. On the other hand, the physiochemical analyses of water indicated low concentrations of ammonium in the Biebrza River (0.00009$-0.00028 \mathrm{mg} / \mathrm{ml})$. It is the evidence for the absorption of ammonium ions, which are formed from organic pollution, by aquatic plants, intensively growing in the warm period in the Biebrza River (Mioduszewski et al. 2004, Frąk et al. 2008). Furthermore, in the conditions of high organic carbon compounds pollution, the nitrogen, formed during their mineralization process, is entirely absorbed by microorganisms, without the release of free ammonium into the surrounding environment (Reinheimer 1987). While the organic substrates are mainly humus compounds, the nitrogen is cumulated in bacteria cells (Carlsson et al. 1999). The research carried out by Frąk (2010) determined high quantities of psychrophilic bacteria, which prove a high availability of nutrients.

In July and September 2007 the nitrifying bacteria of I and II phase were not numerous - maximum $0.09 \mathrm{MPN} / \mathrm{ml}$ of water (Table 2). In July there was a larger number of that bacteria than in September (below $0.03 \mathrm{MPN} / \mathrm{ml}$ ). Alow quantity of nitrifying bacteria (in relation to other physiological groups) is typical for river waters (Reinheimer 1987). Then, the necessity was found to increase the volume of inoculated water. In April 2008, the inoculated volumes for each sample were: $1 \times 50 \mathrm{ml}+2 \times 10 \mathrm{ml}$. The nitrification process was found in each sample of the volume equal to $50 \mathrm{ml}$ (the quantities were not determined). The highest quantities of bacteria were found in samples taken from the points at the Upper and the Middle Biebrza reaches (1-6). At points 7 and 10 the nitrifying bacteria were observed only in the cultures of a higher volume of inoculated water. Generally, in the Biebrza River the quantities of the nitrifying bacteria were discovered 
TABLE 2. Quantitative characteristic of nitrifying bacteria of I and II phase [MPN/ml]

\begin{tabular}{|c|c|c|c|c|c|c|c|c|c|c|}
\hline \multirow{3}{*}{$\begin{array}{l}\text { No } \\
\text { point }\end{array}$} & \multicolumn{2}{|c|}{15.07 .2007} & \multicolumn{2}{|c|}{09.09 .2007} & \multicolumn{6}{|c|}{22.04 .2008} \\
\hline & \multirow{2}{*}{$\begin{array}{c}\text { ph. I } \\
\text { MPN/ } \\
/ \mathrm{ml}\end{array}$} & \multirow{2}{*}{$\begin{array}{c}\text { ph. II } \\
\text { MPN/ } \\
/ \mathrm{ml}\end{array}$} & \multirow{2}{*}{$\begin{array}{c}\text { ph. I } \\
\text { MPN/ } \\
/ \mathrm{ml} \\
\end{array}$} & \multirow{2}{*}{$\begin{array}{c}\text { ph. II } \\
\text { MPN/ } \\
\text { /ml }\end{array}$} & \multicolumn{3}{|c|}{ ph. I } & \multicolumn{3}{|c|}{ ph. II } \\
\hline & & & & & $50 \mathrm{ml}$ & $10 \mathrm{ml}$ & $10 \mathrm{ml}$ & $50 \mathrm{ml}$ & $10 \mathrm{ml}$ & $10 \mathrm{ml}$ \\
\hline 1 & 0.04 & 0.04 & 0.03 & 0.03 & + & + & - & + & + & - \\
\hline 3 & nd & nd & nd & nd & + & + & + & + & + & + \\
\hline 5 & nd & nd & nd & nd & + & + & + & + & + & + \\
\hline 6 & nd & nd & nd & nd & + & + & + & + & + & + \\
\hline 7 & 0.04 & 0.04 & $<0.03$ & $<0.03$ & + & • & • & + & - & • \\
\hline 8 & 0.09 & 0.09 & $<0.03$ & $<0.03$ & nd & nd & nd & nd & nd & nd \\
\hline 9 & $<0.03$ & $<0.03$ & $<0.03$ & $<0.03$ & nd & nd & nd & nd & nd & nd \\
\hline 10 & 0.04 & 0.04 & $<0.03$ & $<0.03$ & + & • & - & + & • & • \\
\hline 11 & $<0.03$ & $<0.03$ & $<0.03$ & $<0.03$ & nd & nd & nd & nd & nd & nd \\
\hline
\end{tabular}

+- nitrification faund; $\bullet-$ nitrification no found; nd - no data

to be similar (Gotkowska-Płachta 2007) or lower than in other river ecosystems (Gołaś et al. 2008a; Gołaś et al. 2008b).

The analyses of water quality performed for July and September, didn't show any presence of nitrites in the Biebrza River water (below detection limit) (Table 3 ). It can be the evidence of a very intensive nitrification process in highly oxygeneted Biebrza water or it might be a proof of seasonal nitrites consumption by other microorganism groups (Carlsson 1999; Frąk et al. 2008; Reinheimer 1987; Gołas et al. 2008a, 2008b). The concentrations of nitrates were also low, from 0.03 to $0.33 \mathrm{mg} / \mathrm{l}$ (Table 3). No trend of their dynamics along the river course was found. Quantitative changes in nitrates concentration are consistent with the changes in nitrification bacteria quantities at individual sampling points.

Low concentrations of available ammonium in water decrease the intensity of nitrification processes (Carlsson et al. 1999), and the same way, the quantity of nitrifying bacteria decreases. Fur- thermore, the research by Olson (1981) indicates, that the activity of the nitrifying bacteria is restricted by the sunlight, which, at the same time, stimulates the assimilation of nitrates by phytoplankton. In transparent and well insolated waters, the I phase nitrifying bacteria are able to compete for ammonium with plancton algae (Reinheimer 1987). The increase of ammonium concentration in the autumn period in the Biebrza River (Skoczko 2004; Kardel et al. 2007) may confirm this thesis: a slow decline in aquatic plants vegetation causes the accumulation of ammonium, which can undergo nitrification. However, the low temperature in this period doesn't allow for the increase of activity and the quantity of nitrifying bacteria.

According to studies by Piechowiak and Kraska (2008) the humus compounds stimulate the growth of nitrifying and ammonifying bacteria, however, they slow down the growth of proteolitic bacteria. In the research performed in this paper, no stimulating action of hu- 


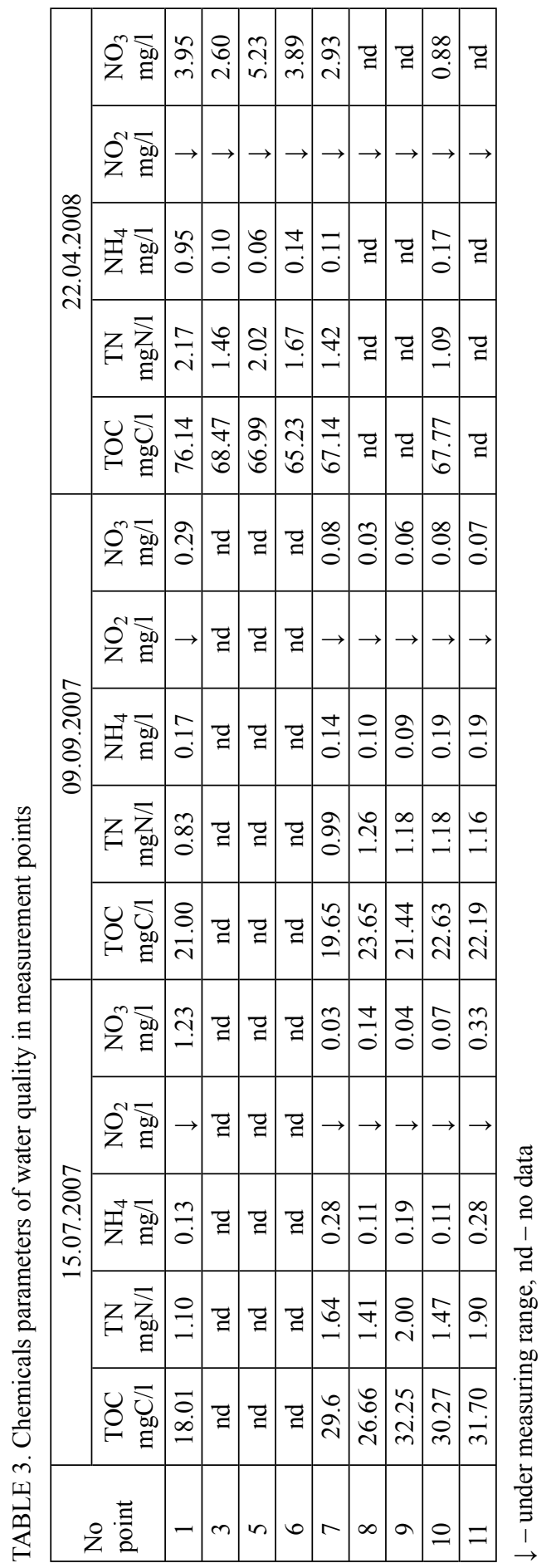

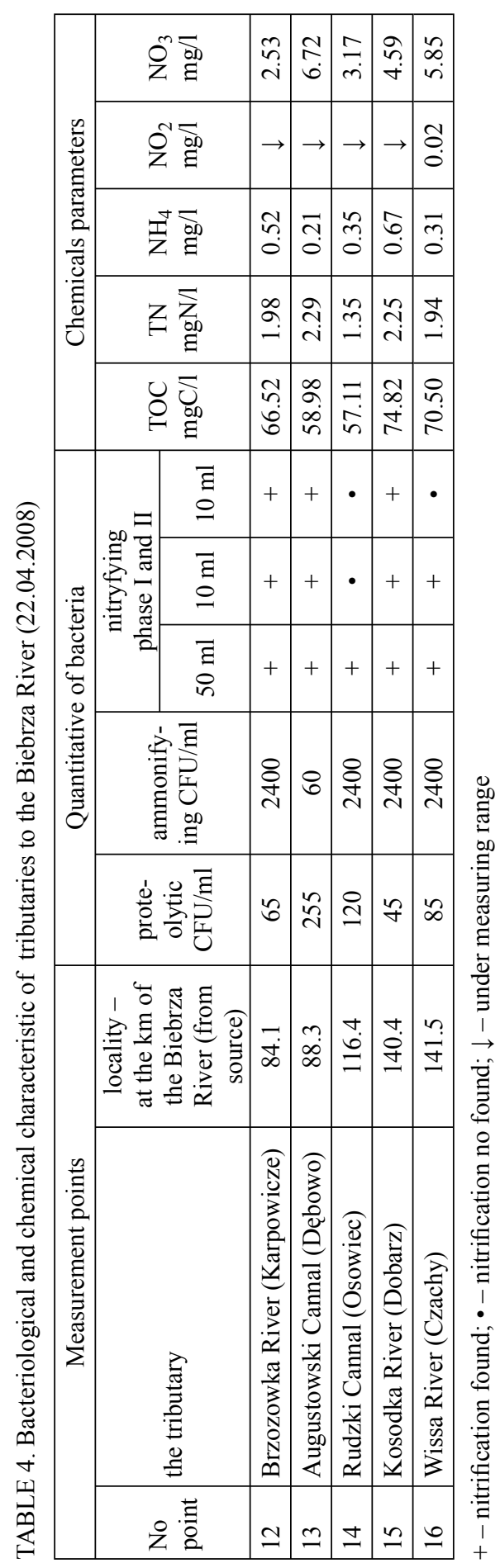


mus compounds, affecting the quantities of nitrifying bacteria, was found (indicating the influence of other factors).

\section{CONCLUSION}

Summing up the general results of the performed research there were noticed high quantities of proteolitic and ammonifying bacteria, while the nitrifying bacteria were few. It indicates high organic matter pollution and vital ammonifying processes, causing the creation of free ammonium. However, the low numbers of the nitrifying bacteria point at low availability of ammonium substrate and as a consequence at low concentrations of nitrates. The results of Biebrza water quality analyses confirm high TOC concentrations and low concentrations of mineral nitrogen forms (ammonium, nitrites and nitrates). Comparing that results with the data presented in relevant, scientific papers, it can be concluded that, the intensity of organic pollution mineralization in the Biebrza River develops according to the seasonality of microorganism occurrence (maximum in the warm period). Moreover, the mineral nitrogen, formed as a result of organic matter degradation, is released to the environment at a low degree. When the right carbon compounds are available, the nitrogen is cumulated in the cells of the bacteria and aquatic plants. Low concentrations of ammonium slow down the growth and limit the presence of nitrifying bacteria.

A low number of the nitrifying bacteria is typical for clean water courses (the Biebrza River), characterized by a low inflow of anthropogenic contaminants.
For the water courses of a low antropopressure degree, but flowing through wetlands (draining them and collecting elements of washed out peat) it is characteristic to observe a high number of ammonifying bacteria without the simultaneous record of high ammonium concentrations.

Within a complete monitoring of a water course state, it is vital to involve also the research on different physiological bacteria groups. The data achieved by that research, in comparison with even phytoplankton dynamics, will make possible to estimate the state of the ecosystems claimed to be clean, where the level of anthropogenic contaminants is low.

Considering the research performed on other water courses and the specific character of the Biebrza River, a low quantity of denitrifying bacteria was assumed and therefore the research on their quantity was resigned from. However, the reports on a vital impact of humus compounds on the quantity of that bacteria type (Piechowiak and Kraska 2008), suggest to verify this assumption.

\section{Acknowledgement}

We thank Master Marta Cendrowska for assistance in implementation of the bacteriological analysis to this paper.

\section{REFERENCES}

CARLSSONP., GRANELIE., SEGATOA.Z. 1999: Cycling of biological available nitrogen in riverine humic substances between marine bacteria, a heterotrophic nanoflagellate and a photosynthetic dinoflagellate. Aquatic Microbial Ecology vol. 18, 23-36. 
FRĄK M. 2010: Zanieczyszczenia bakteriologiczne jako wskażnik jakości wód rzeki Biebrzy. Woda - Środowisko - Obszary Wiejskie 10, 2 (30), 73-82.

FRAॄKM., KARDELI., STELMASZCZYKM. 2008: Phytoseston biodiversity of the Biebrza River against the background of selected water quality parameters - pilot study. In: The functioning and protection of water ecocystems (Gołdyn R. et al., ed.). AMU Poznań Inc., 27-38.

GOŁAŚ I., ZMYSŁOWSKAI., HARNISZM., KORZEKWA K., SKOWROŃSKA A., TEODOROWICZ M., GÓRNIAK D., GROS M., BRZOZOWA S. 2008a: Nitrogen cycle bacteria in the waters of the Drweca River. Polish J. of Environ. Stud. vol. 17, 2, 215-225.

GOŁAŚ I., ZMYSŁOWSKAI., HARNISZM., KORZEKWA K., SKOWROŃSKA A., TEODOROWICZ M., GÓRNIAK D., DUDZIEC E. 2008b: Antropogenic impact on quantitative differentation of nitrogen cycling bacteria in waters of the Drweca River. Pol. J. Natur. Sc. vol. 23, 3, 667680.

GOTKOWSKA-PŁACHTA A. 2007: Wybrane grupy bakterii cyklu azotowego dopływów, toni wodnej i strefy brzegowej Jeziora Hancza. Inst. Ochrony Środowiska in Warsaw Inc. Ochrona Srodowiska i Zasobów Naturalnych 31, 388-393.

KARDEL I., FRAK M., KARDEL I., IGNAR S., OKRUSZKO T. 2007: Influence of Wetlandsom the leaching carbon compounds to the surface waters (Biebrza R.). Polish J. Environ. Stud. vol. 16, 395-401.

MIODUSZEWSKI W., SLESICKA A., OKRUSZKO T. 2004: Problemy gospodarki wodnej. In: The Biebrza River valley and Biebrzanski National Park (Banaszuk H. ed.), 214-264.

OLSON R.J. 1981: Differential photoinhibition of marine nitrifying bacteria: a possible mechanism for the formation of the primary nitrite maximum. J. Mar. Res. 39, 227-238.
PIECHOWIAK M., KRASKA M. 2008: The effect of humic substances on nitrogen cycle bacteria. Ocean. Hydrobiol. Stud. vol. XXXVII, supl. 1, 99-108.

REINHEIMER G. 1987: Mikrobiologia wód powierzchniowych. PWRiL Inc., Warsaw, 327.

SKOCZKO I. 2004: Analiza zanieczyszczenia wybranych dopływów rzeki Biebrzy. Środkowo-Pomorskie Tow. Nauk. Ochrony Środowiska, Koszalin, 245-263.

Streszczenie: Występowanie bakterii cyklu azotowego w wodach rzeki Biebrzy. W niniejszej pracy zbadano występowanie wybranych grup bakterii cyklu azotowego w rzece Biebrzy. W próbach wody oznaczono liczebność bakterii proteolitycznych, amonifikacyjnych i nitryfikacyjnych. Określono poziom wybranych wskaźników jakości chemicznej. Stwierdzono wysoką liczebność bakterii proteolitycznych i amonifikacyjnych oraz bardzo niską bakterii nitryfikacyjnych. Badania chemiczne potwierdziły wysokie stężenia OWO i niskie stężenia azotynów i azotanów. Stwierdzono, że mineralne formy azotu intensywnie powstające w wyniku degradacji materii organicznej nie są uwalniane do środowiska (niskie stężenia amoniaku), a kumulowane w komórkach mikroorganizmów. Niskie stężenia amoniaku działają hamująco na liczebność bakterii nitryfikacyjnych. Stwierdzono ponadto sezonowość występowania wszystkich badanych grup bakterii. Dostosowano procedurę analityczną do wykorzystania w badaniach bakteriologicznych rzek o niskiej antropopresji.

Stowa kluczowe: bakterie amonifikacyjne, bakterie nitryfikacyjne, bakterie proteolityczne, rzeka Biebrza, jakość wody.

\section{MS. received September 2011}

\section{Author' address:}

Katedra Kształtowania Środowiska Szkoła Główna Gospodarstwa Wiejskiego 02-787 Warszawa, ul. Nowoursynowska 166

Poland e-mail: magdalena_frak@sggw.pl 